\title{
Holding Together, Coming Together or Putting Together? A [Re]examination on the Formation of Ethiopia's Federation
}

\author{
K.T. Muluye \\ University of Gondar \\ P.O. Box 196, Gondar, Ethiopia
}

\begin{abstract}
Federations are institutional and struetural arrangements with the tenets of shared rule and self-rule. These federations may be formed through coming together, holding together or putting together processes. Both holding together and coming together federations are established through democratic bargain while putting together federation is imposed coercively by the winners. Hence, this article aims to situate Ethiopia in to one of these three variants through critical [re]examination of the transitional activities. The datatwere collected through interviews and document andysis. A qualitative analysis was employe to analyze the data. Accordingly the paper argues that Ethiopia is a putting together federation because of the major flaw committed during the transition. Particularly, the absence of an organization that could represent Amhara during the Peace Conference, exclusion of the major political organizations from the conference and the aftermath processes as well as the inhuman and extrajudicial treatments against those who were explaining their discontent in the restucturing processes are some of the justification to level Ethiopia's federation as putting together. Moreover, the electoral fraud that forced the major political parties to boycot the elections (the 1992 and 1994 elections) and the manipulation of the drafting and ratification processes of the constitution by TPLF/EPRDF can justify this position. Hence, it $s$ recommended to restructure the federation through democratic bargaining for the putting nature of the federation is facing a legitimacy crisis due to the different questions rooted in the
\end{abstract} formation processes.

Keywords: putting together federation, holding together Federation, Ethnic federalism, Ethiopia's federalism

\section{Introduction}

Federalism, as a "programmatic orientation", advances a "multi-tiered government, which combines elements of shared-rule through common institutions for some purposes and regional self-rule for constituent units for some

(C) Muluye K.T., 2020.

(c) (7) This work is licensed under a Creative Commons Attribution 4.0 International License https://creativecommons.org/licenses/by/4.0/ 
other purposes" [1]. Federations are actual system of governments or polities in which decision-making power is divided between central and regional governments [2]. Since Riker's original work, the formation of federations has been in the centre of intellectual debate. Federations are seen as democracies that are created either through the integration of independent states or the devolution of power to sub-national units [3]. However, Alfred Stepan [4] who saw limitations in such classification identified three types of federations coming together, holding together and putting together federations. Coning together federation are formed by the voluntary agreement of formerly individual polities characterized by a sense of sovereignty and identhy [4]. Holding together federations are formed when a deal is conducted and an agreement is reached in a unitary state [4] such as Ethiopia, which is constuted by multiple ethnicities or other forms of cultural groups [5]. These federation are established through democratic dialogue to curtail separatist te dencies in a unitary state [6]. Putting together federations are formed through "devolution of power" like holding together federations [7]. However, these federations are established through coercive procedures without democratic bargaining among the concerned actors [4]. Given these theoretical lenses, the aim of this paper is to examine and situate Ethiopia's federation in to one of these variants.

Ethiopia, which had been a unitary state for long, was restructured as ethnic federal state in 1991 by "accommodating ethnicity as a fornal poritical element" [8]. Ethnic federalism was preferred to address the "perceived' grievances of different ethnic grouns who were rallying behind the "nationalities question" [7]. Despite consensuses on the reasons for the origin of Ethiopia's federation, it is controversial to situate it in to one of the three variants of Stepan. Authors such as Andreas Eshete [9] argue that Ethiopia's ethnic Jederalism came into effect following the revolutionary overthrown of he long stayed unitary state. For him, Ethippla is reconstructed as a 'a new' political community through the coming toget er of the country's ethnic grouns who had the opportunity to decide over themselves [9]. On the other edge, Assefa Fisseha [1] contends that Ethiopia's federal formation best resembles Stepan s holding together for it was formed through the bargaining of the may or ontenders of power and the then existing contending views. It seems that Assefa's [1] holding together is relatively accepted than Andreas's [ $>$ coming together as the former is taught, as part of a 'universal' knowledge claim, by using civic and ethical education common course given for all freshman university students. However, all of these arguments are shorted from providing well illustrated justification to support their positions and hence the main purpose of this paper is to provide a detail re-examination of the transitional period (1991-995) and to situate Ethiopia's federation in to one of the three variants. Accordingly, the paper aims to:

$\checkmark$ examine the major transitional activities vis-à-vis the principles of democratic bargaining;

$\checkmark$ situate Ethiopia's federation in to one of the three Alferd Stepan's variants;

$\checkmark$ Examine the implication of this federal formation to the legitimacy of the federation. 


\section{Theoretical Arguments on the Formation of Federations}

Federations are created through different manners and for different objectives. These 'why' and 'how' questions in the formations of federations are, thus, bases of intellectual debate in the study of federations though much attention is given to the 'why' questions [3]. William Riker, who is one of the influential contributors to the intellectual debate, argues that federations are formed for military or security purposes [2]. However, the economic factors were also acknowledged and included to be one of the motives for the formations of federations [3]. In addition to the cause, the manner how federations are formed is the issue of concern in the intellectual debate. Based on his analysis of older federations such as the USA, Riker argued that federations are formed through political bargains conducted among political el tes of independent states [7]. In this case, federations are resulted from a bargaining undertaken between two or more independent political entities. These federations are named as coming together federations by Stepan [4]. Coning together federations are formed when individual polities characterized by a sense of sovereignty and identity join other similar polities for certain mutual gains [4]. They are formed by an agreement among leaders at the centre and representatives of constituent units to aggregate territory the territory and economy. In this case, the actors will agree to aggyegate their resources and surrender some of their rights while maintaining autonomy on some other issues [4] In these types of federations, constitutions, which are the covenant among the actors, are resulted from "a series of bargains, agreements and compromises emanating from the interaction of political elites" [3].

Howeyer, Riker's theoretical view on the formations of federations is criticized as it lacks the ability to explain emerging federations in Asia and Africa. Authors, who revewed Riker's propositions with reference to developments in Nigeria, India Malaysia and other states expanded conditions for the origin of federations by including the desire to deter internal threats. In this sense, federations are sought to be institutional arrangements to deter internal threats, such as secession and disintegration, by devolving power from a formerly unitary state to the different ethno-cultural units [6]. In this sense, federations are seen as institutional arrangements establis hed to reduce the risk of secession. Based on his analysis of multi-ethnic federations in Asia, Breen [10] argues that "in each case, nation-building has been based on the dominant group's identity, to the exclusion of smaller ethnic groups and hence federalism comes to be preferred means of accommodation and to overcome the legacies of historical discrimination and exclusion." Such federations are formed through the devolution of power from the centre to the constituent units for the purpose of balancing the interest of centrifugal and centripetal forces unlike Rikerian federations, which are formed through the union of independent states. Hence, unlike, the coming together federation, which is formed through the integration of independent units, holding together federations are formed through devolution of power for managing centrifugal tendencies. Despite Breen [10] calls all such federations as holding together by taking devolution of power as a mere criterion, Stepan [4] adds democratic bargaining to make distinction between holding together and putting 
together federation. Hence, holding together federations are democratic federations that are formed when a deal is conducted and an agreement is reached in a unitary state, which is constituted by multiple ethnicities or other forms of cultural groups, to preserve the national state [4]. In this process, the different political forces will actively engage and reach at a consensus on the main foundations of the federation. This type of federation is established to "maintain a unity of states by establishing a multi-ethnic federal system largely to avoid or settle ethnic, regional and other type of group conflict" [6].

Both the coming together and holding together federations have a common feature of democratic bargaining and they are genuine federations. For some, federations that are not instituted based on the principles of democratic bargaining are 'not' even federations. For instance, for Burges [3], ' ederations are voluntary unions based firmly upon liberal democratic notions of constitutional government..." and hence "coercive unions such as the old Soviet Union, Argentina, Brazil and Nigeria shall be rule out from the list of federations when they suffered intermittent periods of nilitary government". As such, principles of democratic bargaining such as equality, inclusiveness, consensus, and representations are crucial ideals in the establishment of holding together and coming together federations [4].

However, the equation of federations with democracy is not found to be satisfactory to explain federations, which have undemocratic features Freeman cited in Burges [3] states that "federal governments can be democratic on undemocratic. Similarly, Aalen [4 points that "it is important to acknowledge that federal projects might take a variety of forms which cannot be simply equated with late modern democracies" Aceordingly, Stepan [4], who aspires to deconstruct the notion that equates federations with democracies, identify a third variant: putting together federation. Despite putting together federations are established through devolution of power like holding together federations [7], they are established through coercive efforts zulike holding together federations, which are formed through democratic bargaining [4]. Putting together federations, llike the former Soviet Union, are established through a heavily coerefve effort by a non-democratic centralizing power to put together different ethnic group within a multinational state" [4]. In this type of federation, principles such as equality, inclusiveness, genuine representations, consensus, and impartiality that are detrimental in holding and coming together federations [3] cannot be given a due attention. Instead such federations are established through forceful efforts. Taylor [2], who also studied the Russian federation, wrote as "the critical role of force in the federal bargain was evident in the very manner in which the 1993 constitution of Russia was adopted". For this author, Russian federation and the constitution are imposed by President Yeltsin through coercive measures without consented deliberations with its oppositions in the parliament [2]. "Control over the army, police, and secret police was fundamental to Yeltsin's victory...and the constitutional framework for Russian federalism was largely imposed by Yeltsin" [2]. This type of federation is a federation where the winning/dominant group/s decides the formation of the federation, the contents of the federal pact, the criteria for internal boundary demarcations and all other issues. The 
implementations are also handled through coercive procedures [4]. Given this theoretical benchmark, this paper aims to examine the processes of the federal formation in Ethiopia and situate it in to one of the three variants.

\section{Methods and Materials}

This paper seeks to examine the process through which Ethiopia's federation was created. For this purpose, a qualitative research method was employed. It is interpretative approach concerned with understanding of the meaning of words that people attach to phenomena [11]. Thus, this approach is used to explore the experiences that were faced by the different actors of the transition mainly by using secondary sources such as reports of international organizations, research reports published by reputable research journals, media archives where the interviews of eminent figures such as Lencho Leta (who was the actor through his party, OLF) are achieved. Moreover, interviews were used to collect data. Individuals (mainly leaders of political parties both from the opposition and the incumbent) were consulted to collect a primary data. From leaders of the incumbent parties, one official from the federal House of Federation, two officials from Amhara Democratic Party (ADP, former Amhara National Democratic Movemen (ANDM)), two officials from ODP (Oromo Democratic Party (ODP; former OPDO) and one Veteran from Tigrean People Liberation Front (TPSF) were chosen. Among the opposition political parties, two from National Mo ement of Amhara (NaMA), two former officials of All Amhara People's Organization (AAPO), one from Ethiopian People Revolutionary Party (EPRP) and two officials from Ethiopian Federal Democratic Unity Forum-akaMedrek were chosen. The interview participants were chosen purposively based on their familianty to the issue. The interviews were conducted from JanuaryFebruary 2019 and each interview consumed an average of an hour. In relation to researchethics, consent is obtained from eachinterviewee. Moreover, their names are kept anonymous in the analysis to protect their security. Finally, the data collected though the interviews and document analysis were analyzed though a quaritative thematic analysis.

\section{The formation of Ethiopia's Federation}

Ethiopia is one of the ancient countries with a long history of independent statehood. The modern Ethiopian state emerged at the second half of the $19^{\text {th }}$ century with the ascension of Tewodros II in 1855 to the throne [1]. From this time onwards, the successive Ethiopian leaders were eager to create a unified Ethiopia. Hence, the state and nation building processes were undertaken together by the successive regimes. Minelick II successfully undertook a series of military conquests and peaceful submission strategies to unify the state [1]. Indeed, his legacy is the emergence of Ethiopia with its present geographic shape and ethnic makeup [12]. The successive rulers were attempting to consolidate the nation building process through an assimilation policy, where Amharic language and Amharan culture was considered to be mainstream/national identity [13]. 
However, this process was criticized for it rejects the multiethnic nature of the state [14]. As a result, "Ethiopian students started to use Stalinist theory of nationalities to narrate problems of ethnic relations in Ethiopia" [7]. Since the beginning of the 1960s, the imperial government begun to face opposition from increasingly radicalized students who rallied behind land to the tiller, and the nationalities' question, copied from Stalin of Russia [7]. Along with this, different organizations were created to liberate their respective ethnic gyoups from "Abyssinian colonialism" [13] or suppression [1]. Ethno-nationalis groups such as the Oromo Liberation Front (OLF) claim that Abyssina (the historic core of Ethiopian polity) colonized roughly half the territopies and peoples and their struggle is to end this colonial empire-state [15]. Similary, TPLF was claiming that all the miseries that were faced by Tigray people are due to the deliberate actions of the Amharan rule [16]. Hence, there struggle was to end Amhara domination [1] or liberation from "Abyssinian colonialism" [14]. With such political narrations, the ethnic nationalist forces keep being established and continued their struggle against the Dergue regime. Despite there were many organizations, the dominant were Eritrean People Liberation Front (EPLF), TPLF and OLF [17]. These forces along others such as All Ethiopian Socialist Movement (AESM), EPRP and Ethiopian Democratic Union (EDU, undertook a struggle against the Dergue regime and Dergue was removed fron power ir 1991 [7]. Following the overthrown of the Dergue regime, the winners, led by TPLF/EPRDF, restructured the country as a federal state 40 meet the presumed ethno-regional grevances of the various groups (especially their elites) in Ethiopia" [18].

TPLF/EPRDF with OLF (at least for a year) restructured Ethiopia as ethnic federal state [19]. They decided the criteria opredistrieting the country [20]. Accordingly the country was divided in to 14 constituent units, which later reduced in to nine regions based on language, et nicity, settlement pattern and willingness of the people [21: art.46]. However, language and ethnic identity were the main criteria of internal boundary demarcations [7]. TPLF/EPRDF, which controlled the power following the withdrawal of OLF from the Transitional Government of Ethiopia (TGE in 1992, was the main force behind the making and unmaking process of Ethiopra [8]. As a result, this paper argues that the formation of Ethiopia's federation is not resulted from democratic bargaining and hence it best fits Alferd Stepan's putting together variant. Here below, the paper presents the main arguments to justify why Ethiopia's federation has to be identified as putting together federation.

\section{Exclusion of Contending Political Parties from the Peace Conference}

The restructuring process was begun by the July 1991 Peace and Democracy Conference. This conference was the base for the adoption of the Transitional Charter through which the TGE was established. As such, the inclusion and participation of political movements with different political positions would have been crucial if the federation was to be established through a genuine federal bargain. However, the major contending political organizations were excluded 
from the Peace Conference (interviewee from EPRP, 26 January 2019, Addis Ababa). TPLF/EPRDF, which was enjoying a leadership role and capitalizing its commanding position, had dominated the political landscape by virtue of its military power and hence excludes contending powers from the peace conference [20]. Among the excluded political organizations, the main were EPRP, AESM, and other members of Coalition of Ethiopian Democratic Forces (COEDF) [17].

It is argued that these political parties were excluded from the process for they were not willing to abandon their military struggle (interviewee from ADP, 04 January 2019, Bahirdar). Others, on the other hand, argue that these political parties were excluded since their political orientation was far from EPRDF's position on the rights of nations, nationalities and peop e of Ethiopia (Interviewee from EFDUF, 24 January 2019, Addis Ababa). In relation to this, Aalen [19] also ascertained that "individuals or movements which had been affiliated with Mengistu's WPE or organizations with a non-ethnic base (like the EPRP) were excluded".

Based on the interview with an academician at Addis Ababa University and higher official in EFDUF, those parties who attended the conference and latter became part of the TGE were even weak parties that could not bargain with TPLF/EPRDF. Thus, the conference vas not accommodative to competent political parties while it was open to weak parties that were easily manipulated by the then dominant party. If the competent political parties were allowed to take part and the conference was conducted among equals, it would not be concluded with the adoption of TPLF' solitical program as a Transitional Charter vithout a change. In relation to this, Aalen ([19] writes as "The Transitional charter, which worked as an interim constitution, adopted EPRDF/TPLF's ideas largely unmodified, although the OLF played an important part in the shaping the document". Moreover, its exclusionary practices allowed TPLF/EPRDF to secure the largest seats in the unelected Council of Representatives of the TGE (interviewee from EFDUF, 24 January 2019, Addis Ababa). "EPRDF controlled 32 seats while its "junior partner", OLF secured 12 seats out of 87 total seats" [17]. It also controlled key executive powers of the TGE, which was one of the reasons that led to the quarrel with OLF (interviewee from EFDUP, 24 January 2019, Addis Ababa). Generally, when one carefully examines the admission criteria for the conference, the actor who prepared and controlied the conference, the agenda setting process, earlier arrangements, exclusion of major contending political parties and the like; it is convincing to conclude that Ethiopia's federation is not resulted from inclusive bargaining. This is in contrast to the fact that democratic bargaining is the most essential prerequisite in the formation of federations.

\section{Controversies on the Involvement of Amhara in the Restructuring Process}

While different (or at least the main) ethnic groups were represented by different organizations, it is claimed that Amhara was not dully represented during the restructuring process and hence the federation is not legitimate (Interviewee from NaMA, 15 January 2019, Baihrdar). This political narration is firmly held by the Amhara based opposition party, NaMA. Interviewees from ADP also share the 
idea that there has to be constitutional modification and restructuring of the federation for the reason that Amhara's interest were not dully articulated and entertained during the transition (interviewee from ADP, 04 January 2019, Bahirdar). In spite of the fact that there was not any ethnic based political party that could represent the Amhara, the arguments that there were not Amharas in the process is not convincing for the reason that many Amharas were participating in the process as members of Ethiopian People Democratic Movement (EPDM) (interviewee from ODP, 19 January 2019, Addis Ababa). However since EPDM was a multinational party, its struggle to articulate and defend the interest of Amhara, as compared to other ethnic based political parties, was negligible (interviewee from ADP, 04 January 2019, Bahirdar).

The participation of Amhara in the restructuring process is essential not only for its large numerical size (as it is the second largest) but also for being the main group that played a significant role in the state and nation building process of Ethiopia [22]. According to Kidane [17] 'three dentities: the Oromo, Amhara, and Tigray are the most predominant, and suceess of the federal arrangement is likely to, largely but not exclusively, hinge on the configuration of power among the elites of these three identities". However, though Amharas were part of the process through EPDM, they were not as a strong as the ethnic based parties to articulate the interest an positions of the Amhara (interviewee from ADP, 16 January 2019, Bahirdar. This gave an opportunity for the ethnic based parties to determine the whole principles of the restructuring process in the absence of an equivalent ethnic based political movement that could represent Amhara. The main recurrent questions against the boundary demarcation, the politics of recognition and the narration about titular versus non-titular classifications that made Anhara though it also affects other minorities too) to be a victim were framed in its "absence".

Being cognizant of this problem, AAPO was established to articulate the interest of Amhara (the Guardian 25 May 1999). However, as it was common to other opposition political parties, TPLF/EPRDF was intimidating, arresting, harassing and killing the leaders members and supporters of the party (Amnesty International 1994). Soon after its foundation in January 1992, several officials of AAPO including the chairperson Professor Asrat Woldyes were arrested [23]. According to the report of the Immigration and Refuges Board of Canada (1996), from the total of 14 executive Committee of the party, 12 were arrested in between 1993 and 1995. Moreover, at around 2000 supporters and members of the party were arrested in between 1992 and 1993 [23]. Due to such inconveniencies, it is claimed that it was difficult for the Amharas to articulate their interest and positions in the restructuring process of Ethiopia (interviewee from NaMA, 18 January 2019, Bahirdar). Then, it was with in this context that EPDM - a multinational TPLF's affiliated party - was changed in to Amhara National Democratic Movement (ANDM, the current ADP) in 1994 (interviewee from ADP, 04 January 2019, Bahirdar).These all demonstrates how Ethiopia was restructured in a manner where opposition political organizations that claim to represent the Amhara were forced out. The federation was imposed through force 
where those with opposition voices were facing frequent intimidations, arrest, killing, detention, and even disappearance.

\section{Power Monopolization through the Creation of Incompetent Parties}

When TPLF recognized that it becomes victorious of the war, it understood that it could be difficult to assume political supremacy in the country since it represents small population [19]. As a result, it planned two techniques to ensure its political domination. The first one was to establish a nationvide political party, which would be under its own control [7]. However, the effort of building a nationwide Marxist-Leninist party ended in 1990 because of the collapse of socialism at the global level [7].

The second plan was establishing a front by creating member political organizations that "represent" the differen nethn groups [7]. In lieu of this strategy, TPLF created a broader based movement i.e. EPRDF in 1989 with a membership of EPDM [19]. When its pran to establish a nationwide MarxistLeninist party was halted by 1990, TPLF opted for the second strategy and continued to create other parties Accordingly, OPDO (the current ODP) was created in 1990 to represent the Oromo people when OLF was not found to be submissive and obedient [14]. As stated earlier, EPDM was changed to ANDM (the current ADP) in 1994 to represent the Amhara people when AAPO attempts to mobilize this people through its ethnic identity. Southern thiopia People Democratic Front (SEPDF) was created in 1994 to "represent" the Southern Peoples when the Southern Ethiopia People Democratic Coalition (SEPDC) criticized the authoritarian character of the TGE [19]. These parties, for they were created by TPLE, were obedient to their creator rather than defending the interests of the people whom they claim to represent interviewee from EFDUF, 24 January 2019, Addis Ababa). This idea is even shared by officials from ADP "though we were the member of the govening coalition, TPLF was the dominant political power and many of the decisions were made based on its interest" (interviewee from ADP, 4January 2019, Bahirdar). Hence, "though EPRDF embraces various organizations TPLF dominates EPRDF to such an extent that EPRDF has been considered as a deceptive euphemism for TPLF" [20]. Because of this, it is not convincing to claim that Ethiopia's federation is formed by federal bargaining among equals.

\section{Electoral Frauds and Power Consolidation}

As part of the transitional process, elections were held in 1992 (for local and district level councils) and 1994 (for the Constitutional Assembly). Conditions leading to and during the election, however, were not conducive to opposition political parties. TPLF/EPRDF leaders were claiming that they are the only legitimate rulers since they overthrown Dergue. "We [the EPRDF] fought for 20 years, and it is not fair that any party born yesterday should compete with us. We will fight to keep the power" [19]. Such attitudes forced EPRDF leaders to be intolerant for competitive political forces. TPLF/EPRDF, which dominated the armed forces by providing two thirds of the soldiers [20], was undertaking 
intimidation and harassment against the leaders and members of legally registered political parties [17]. It was employing violent and undemocratic tactics to upset election proceedings in order to maintain power (interviewee from EFDUF, 24 January 2019, Addis Ababa).

People in political oppositions were arrested, intimidated, harassed, killed and tortured. Many leaders and members of OLF, EPRP, AAPO, Sidama Liberation Movement (SLM) and Ogaden National Liberation Front (ONLF) were facing various intimidations [23]. The torture methods include tyin the victims' arms together tightly behind their backs with plastic strips, depriving them of food, death threats and mock executions [23] which all are admitted by the new administration which forced the premier to ask an apology in front of the parliament (interviewee from ODP, 16 January 2019, Ad (is Ababa).

These behaviours of the incumbent forced many of the strong political parties to boycott the elections [24]. Though AAPO and OLF were the major competing organizations at that time [19], they were forced to boycott both the 1992 and 1994 elections, which left EPRDF without meaningful opposition [24]. Hence, TPLF/EPRDF controlled the political space and won the elections with the help of multiple electoral frauds 24]. His within these manners, members of the Constitutional Assembly ${ }^{1}$ were elected. Thus, TPLF/EPRDF controlled the Constitutional Commission a body which was organized by the TGE to prepare the draft constitution) and the Constitutional Assembly hrough which it manipulated the drafting andratification processes of the constitution [44].

It is apparen that the process behind the new constitution was even less inclusive and participatory than the process behind the transitional charter. In the constitutional process, the EPRDF totally dominated the scene. It is therefore impossible to conclyde that the final confirmation of the federal solution through the constitution was based on a pact or covenant between contending political forces.... The new constitution, the main doetmen for legalizing and formalizing the federal system, was ratified by a Constitutional Assembly controlled by the ruling party [19].

Consensus is very crucial to come up with a legitimate federal pact. However, the FDRE constitution lacks this legitimacy (particularly by the Amharas) since the ratification and drafting processes were not democratic (interviewee from NaMA 04 January 2019, Bahirdar). The election for the Constitutional Assembly was undertaken in a manner where competent parties were forced to boycott the elections due to repetitive arrest, intimidation, killing and tortures against the leaders and the members of these parties. The Commission was also criticized for it was dominated by individuals who had affiliation to TPLF (interviewee from ADP, 15 January 2019, Bahirdar). Hence, the partiality in the selection of the members for the constitutional commission and frauds in the election process (both the 1992 and 1994) are the other justifications to the putting together nature of Ethiopia's federation. Generally,

${ }^{1}$ The Constitutional Assembly was the body that was directly elected by the "Nations, Nationalities and Peoples" to adopt the draft constitution while the Constitutional Commission was the body that was organized by the TGE to prepare a draft constitution. 
this paper argues that Ethiopia's federation came into effect without a meaningful democratic bargaining. The peace conference, the institutionalization of the TGE, the 1992 local and district level election, the 1994 election for a Constitutional Assembly were dominated by TPLF/EPRDF. The political organizations with alternative programs were forced to withdraw from the processes through coercive measures. Thus, these all indicates how Ethiopia's federation has to be identified as a putting together federation.

Because of this putting together federation, which came into effect without meaningful deliberation and consented agreement, different ethno-linguistic groups raise recurrent questions in relation to internal boundary demarcations and substate's politics of recognition. The different ethno-regional groups have claims against the boundary demarcation and many of the conflicts dubbed as ethnic conflict in Ethiopia are, mainly, associated with this border issue [5]. The exclusion and marginalization of minorities at the sub-state levels is also the other serious issue to which the federation is criticised [12]. These, in turn, are affecting the legitimacy of the federation and some of the ethnic groups such as Amhara requests for the reconstruction of the federation while others such as Oromos, Somali and Afar needs for the resolution of the border issues under the existing federation (interviewee from the House of Fedetation, 17 January 2019, Addis Ababa).

\section{Conclusion}

This paper examined the formation of Ethiopia's federation. The transitional period, where the major events to restructure Ethiopia as a federation were concluded, was characterized by single party, TPLF/EPRDF, supremacy. Hence, Ethiopia is a putting together federation in which the federal arrangement was imposed by this dominant power (TPLF/EPRDF) rather than being resulted from a democratic inclusive, and impartial federalibarganing. Particularly, the absence of an organization that could represent Amhara during the Peace Conference, exclusion of the major political organizations from the conference and the aftermath processes as well as the mhuman and extrajudicial treatments against those who were explaining their liscontentin the restructuring processes are some of the justification to level Ethiopra's federation as putting together. Moreover, the electoral frauds that foreed the major political parties to boycott the elections (the 1992 and 1994 elections) and the manipulation of the drafting and ratification processes of the constitution by TPLF/EPRDF can justify this position.

This putting federation left many issues such as unresolved claims of minorities at the level of sub-sate political units and border issues as bones of contentions among the different ethno-linguistic groups. Hence, it is recommended for the government of Ethiopia to reconsider Ethiopia's federation through democratic, genuine, peaceful, consented, and inclusive federal bargaining.

\section{REFERENCES}

[1] Assefa F. Federalism and the Accommodation of Diversity: A Comparative Study. Netherlands: Wolf Legal Publisher; 2006. 
[2] Taylor B. Force and Federalism: Controlling Coercion in Federal Hybrid Regimes. Comparative Politics. 2007; 39 (4): 421-440.

[3] Burges M. Comparative Federalism: Theory and Practice. London: Taylor and Francis Group; 2006.

[4] Stepan A. Toward a New Comparative Politics of Federalism, (Multi)nationalism and Democracy: Beyond Rikerian Federalism. Arguing Comparative Politics. Stepan A. (ed.). London: Oxford University Press; 2001.

[5] Abbink J. Ethnicity and Conflict Generation in Ethiopia: Some Problems and Prospects of Ethno-Regional Federalism. Journal of Contemporary African Studies. 2006; 24 (3): 389-413.

[6] Wondosen T., Zahorik, J. Federalism in Africa: The Case of Ethnic Based Federalism in Ethiopia. International Journal of Human Sciences. 2008; 5 (2): 1-39.

[7] Asnake K. Federalism and Ethnic Conflict in Ethiopia: A Comparative Study of the Somali and Benshangul-Gumuz Regions. Leiden Wniversity publisher; 2009.

[8] Abbink J. Ethnic-based Federalism and Ethnicity in Ethiopia: Reassessing the Experiment after 20 Years. Journal of Eastern African studies. 2012; 5 (4): 596-618.

[9] Andreas E. Ethnic Federalism: New Frontiers in Ethiopian Politics. Contribution Presented on the First National Conference on Federalism, Conflict and Peace Building. Addis Ababa; 2003.

[10] Breen M. The Origins of Holding-Together Federalism: Nepal, Myanmar, and Sri Lanka. Publius. The Journal of Federalisn. 2017; 48 (1): 26-50.

[11] Creswell J. Research Designs: Qualitative, Quantitative and Mixed Meihods. 3rd ed. Sage publishing; 2009.

[12] Bekalu A. Ethnic Cleansing in Ethiopia. The Canadian Journal of Peace and Conflict Studies. 2018; 50 (1): 77-104.

[13] Mekuria B. Gentocidal Violence in the Making of Nation and State in Ethiopia. African Sociological Review. 2005; 9 (2): 1-54.

[14] Merera G. Ethnicity, Democratization and Decentralization in Ethiopia: The Case of Oromia. Eastern Africa Social Science Research Review. 2007; 23 (1): 81-106.

[15] Habtu A. Ethnic Federalism in Ethiopia: Background, Present Conditions and Future Prospects. Contribution presented on the International Conference on African Development; 2003. URL: https://scholarworks.wmich,edu/africancenter_icad_archive/57. Accessed: 10.11.2019.

[16] Bekalu A. Ethnic Federalism and Con tict in Ethiopia. African Journal of Conflict Resolution. 2017; 17 (2): 41-66.

117] Kidane M. Identity Politics, Democratization and State Building in Ethiopia's Federal Arrangement. African Journal of Conflict Resolution. 2007; 7 (2): 63-92.

[18] Abbink J. The Ethiopian Second Republic and the Fragile "Social Contract". Africa Spectrum. 2009; 44 (2): $3-28$.

[19] Aalen L. Ethnic Federalism in Dominant Party State: The Ethiopian Experience, 1991-2000. Developmen Studies and Human Rights Report - 2002. Bergen: Chr. Michelson Institute; 2002 URL: https://core.ac.uk/download/pdf/59168136.pdf. Accessed: 05.01.2017.

[20] Alemante G. Ethiopia: Problems and Prospects for Democracy. William and Mary Bill of Rights Journal. 1992; 1 (2): 205-226.

[21] Federal Democratic Republic of Ethiopia. Constitution of the FDRE. Addis Ababa: Mega Printing Press; 1995.

[22] Levine D. Greater Ethiopia: The Evolution of Multiethnic Society. London: The University of Chicago press; 1974.

[23] Amnesty International Report 1994 - Ethiopia: 1 January 1994; 1994. URL: http://www.refworld.org/docid/3ae6a9f512.html. Accessed: 20.01.2019.

[24] Lyons T. Closing the Transition: The May 1995 Elections in Ethiopia. The Journal of Modern African Studies. 1996; 34 (1): 121-142. 


\title{
Держаться вместе, идти вместе или собираться вместе? Пересмотр вопроса о формировании федерализма в Эфиопии
}

\author{
К.Т. Мулуйе \\ Университет Гондэр \\ 196, Гондэр, Эфиопия
}

\begin{abstract}
Аннотация. Федерации основаны на принципах совмеслного правления и самоуправления. Федерации могут быть сформированы на сенове различных моделей объединения: как посредством «демократической сделки», так и том случае, когда федеративная модель навязывается победителями принудительно. Целью данной статьи является анализ модели федерализма в Эфиопии посредством кри ического рассмотрения переходного процесса. Автор опирается на данные, собранные при помощи интервью и анализа документов. Для анализа полученных данных был использован качественный анализ. В статье утверждается, что Эфиопия является фе ерацией объединяющего типа из-за серьезных ошибок, допущенных в период переходног периода. К таким ошибкам автор относит, в частности, отсутствие организации, которая могла бы представлять народ Амхара во время Мирной конференции, исключение основыых политических организаций из участия в конференции и последующих процессов государственного строительства, а также жес окое и внесудебное обращение с от ельными гражданами и общественными деятелями, выражавшими недовольство процессами федерализации после 1991 года. Такке автор полагает, что становление эфиопокой модели федерализма сопровождалось фальоификациями на выборах, которые в нудили основные политические партии бойкотировать парламентские выборы 1992 и 1994 годов, а также манипуляциями в ходе процесса разработки и ратификации Конституции со стороны партии РДФЭН. В заключение статьи автор рекомендует реструктурироваь фе еративную систему Эфиопии посредствомдемократических переговоров, так как в настоящий момент она сталкивается с кризисом легитимности.
\end{abstract}

Ключевые слова: Эфиопия, федерапия, этнический федерализм, эфиопский федерализм, Конституция

Информация об авторе:

Китемо Тируне Мулуйе - прейодаватель кафедры гражданских и этических исследований Университета Гондэк Эфйопия) (ORCID ID: 0000-0001-6104-8807) (e-mail:

ketemaw.muluye@uog.edu.et).

\section{Information about the author:}

Ketemaw Tiruneh Muluye - Lecturer of the Department of Civic and Ethical Studies, University of Gondar (Ethiopia) (ORCID ID: 0000-0001-6104-8807) (e-mail: ketemaw.muluye@uog.edu.et).

\section{Для цитирования:}

Muluye K.T. Holding Together, Coming Together or Putting Together? A [Re]examination on the Formation of Ethiopia's Federation // Вестник Российского университета дружбы народов. Серия: Государственное и муниципальное управление. 2020. T. 7. № 1. С. 70-82. DOI: 10.22363/2312-8313-2020-7-1-70-82

\section{For citation:}

Muluye K.T. Holding Together, Coming Together or Putting Together? A [Re] examination on the Formation of Ethiopia's Federation. RUDN Journal of Public Administration. 2020; 7 (1): 70-82. DOI: 10.22363/2312-8313-2020-7-1-70-82 